\title{
The Living Building and Teaching Through Environments
}

Magdalena Rudkowski

Simon Fraser University

"The more time you spend with children, the more you notice how inquisitive they are about the world and how keen is their thinking even about the most subtle things - things which escape materiality, easy recognition, definite forms, and the laws of invariance, things you can touch but can't touch, that brush against the real and imaginary, that have something of the mysterious about them and offer wide margins of interpretation" - Loris Malaguzzi

My personal childhood experience in combination with over ten years studying and working with young children has led me to become passionate about children's relationships and understandings of the natural world and the innate curiosity that young children hold in the early years of their lives.

As a young child, I spent most of my days in the outdoor world: playing hide-andseek with a group of friends, climbing trees that to us were known as 'rocket-ships', following streams and exploring rocks - all by the age of seven. Now, as an adult, I have come to reflect upon my own childhood years with great gratitude for the natural world and for helping me to become the individual I am today. With society changing and technology quickly evolving, I have come to understand that this type of play has been slowly replaced by a different and more structured kind of play (Singer, Singer,D’Agostino \& DeLong, 2009; Clements, 2004). It's also a known fact that the environment around us is changing and that environmental sustainability has drawn more awareness in our public society. A 
'green movement' has touched upon every aspect of our lives: the products we use, the food we consume, the buildings we built, and how we learn about our outdoor environment.

The early years of a child's life are the most significant in forming life-long habits and worldviews (e.g. Wells \& Lekies, 2006; Chawla, 1998; Wilson, 1996; Samuelsson, 2011; Palmer, Suggate, Robottom, \& Hart, 1999). It is the time when children are most curious, forming their understandings and perceptions about the world around them. They are a part of the environment in which we live; they are the stakeholders who will lead the following generations. Yet, while education for environmental sustainability has been taking shape in the public school system and adult-education programs, it is clear that the early years have been mostly overlooked in North America ${ }^{1}$. This has been pointed out by researchers such as Davis (2009) who conducted a scan of environmental education in the early childhood years. She found that early childhood education researchers rarely engage with sustainability issues, while environmental researchers rarely engage in early childhood education issues. This points to several major gaps in the literature, such as: young children's understandings of environmental sustainability, family values and related habits, and pedagogical theories addressing how an early-years setting could cultivate understandings and positive behaviours regarding environmental sustainability, as well as the implications of such initiatives.

As part of my Curriculum Theory and Implementation doctoral program in the Faculty of Education, I intend to focus my dissertation to explore some of these issues. In

\footnotetext{
${ }^{1}$ This is not the case in Australia, New Zealand and the Scandinavian countries, where the early childhood curricula policies strongly engage in early childhood environmental sustainability (ECES) practices.
} 
April of 2012, the UniverCity community opened its doors to the Living Building, an environmentally sustainable childcare centre—-the first 'living' building in North America. The SFU Community Trust developed the building with a goal of going beyond the conventional building codes and standards. The project was entered into the Living Building Challenge to try and make the building the most advanced green building in the world. The Living Building Challenge program has 20 imperatives under 7 categories (or Petals) of site, water, energy, health, materials, equity and beauty. For instance, the materials used to build this childcare had to come from local sources within certain radius of the site (depending on the density of the material; i.e., the heavier materials must be sourced from shorter distances). Or, all building materials were thoroughly screened to eliminate "Red List" chemicals such as PVC, formaldehyde, pthalates, heavy metals (such as lead and mercury) and a host of other harmful materials. All wood used in the project is either salvaged or certified under very strict environmental requirements of FSC (Forest Stewardship Council) certification. Most of the structural wood is from pine-beetle-killed forests of BC.

Aside from drinking water, which has health restrictions, all water used in the childcare centre (e.g., toilets and laundry) is from rainwater. The rainwater is collected in a 40,000-litre tank buried under the playground. The building also treats its entire sewage and wastewater on-site. The clean treated water is dispersed underground to recharge the local aquifer. The solar hot water panels on the roof generate enough energy to offset all energy used by the building (electrical and heat combined). It is directly connected to the UniverCity neighbourhood energy system, which means the excess energy generated in summer or warmer times of the year could be distributed among neighbouring buildings. 
Conversely, when the solar panels cannot generate enough energy due to the long periods of overcast sky or cold snaps, the neighbourhood energy system could provide (give back) the required energy to heat the building. The SFU UniverCity Childcare has many other sustainable features that deal with other Petals of the Living Building Challenge. Perhaps the childcare centre could be best summarized with the words of Jason McLennan, CEO of the Living Building Institute, who called it the "greenest childcare on the planet" (SFU News, 2012, June 21).

The childcare is currently housing children aged three to five years and follows a Reggio Emilia philosophy, which views children as competent, creative individuals with a wealth of knowledge. The building is structured in accordance to the Reggio Emilia approach, following an open-concept layout where two rooms come together and form a part of the childcare centre called the "piazza" (otherwise known as the 'town square'). This provides an opportunity where children are able to interact and collaborate. The Reggio Emilia approach also stresses that the indoor environment reflects the surrounding world. The Living Building childcare follows this by having windows which extend from floor to ceiling, as well as providing natural play and toxic free materials. In this way, the childcare environment is known to be a third teacher for a child's learning, where it offers an ample amount of opportunities for learning through exploration, play and research. It is this distinctiveness of this childcare's structure and overall philosophy that encouraged me to pursue my thesis specifically on this centre.

Due to uniqueness of the building, it is vital to explore how the children of the centre interact with its features in how they use the space. As this is an environmentally friendly building, it is equally important to understand how the environmental sustainability 
philosophy is modelled to and understood by the three to five year old children at the centre. How do the children understand environmental sustainability and the Living Building design concepts? How do the early childhood educators understand the Living Building design concepts? How does the Living Building childcare environment and curriculum cultivate environmentally sustainable behaviours and understandings? How do the homelives of the children compare with the Living Building's environmental philosophy? I hope to answer these questions and more throughout my research process.

In line with Reggio Emilia's philosophy, I will follow a methodology that views children as capable and knowledgeable individuals. This will be done by involving the partaking children with the research process as well as actively participating in their everyday worlds, asking questions using creative methods of group interviews and through ongoing casual opportunities, observations and creative activities (e.g. photography, drama, visual arts). By seeking out their opinions and understandings, I strive to successfully conduct research with children as opposed to on children. Adding to this, I hope to engage the childcare community and seek their understandings and perspective regarding the building and concepts of environmental sustainability. This will allow me to form a wellrounded perspective on what the community understands about the building itself and environmental sustainability, and if or how these ideas are modelled to the children.

I would like to end of my piece by reflecting upon the fact that young children have a unique set of skills that should be respected in educational pedagogies. Young children learn through their own curiosities of exploration, experience and through their primary senses of seeing, hearing and feeling. This holistic learning methodology needs to be central in environmental sustainability education in the early years. This type of education 
needs be woven into their daily lives, and modelled by other peers and caregivers. It needs to be relevant to their own, personal lives - focusing on the child's interests that are relatable to their daily activities. This education cannot be 'transferred' by direct instruction; rather, opportunities in play need to be presented for a child to tackle when interested. In addition to cultivating a relationship with the natural world in the early years (see Sobel, 2008), children need to have the opportunity to understand the importance of conserving energy and caring for the outside world in ways that are fitting to their own lives and intimate communities, and to the developmental strengths that they hold. The worst we can do is to scare children by following the 'doom and gloom' approach or by bringing dullness into their lives, or as Sobel (1999) popularly coined it, ecophobia.

\section{References}

Chawla, L (1998). Life paths into effective environmental action. The Journal of Environmental Education, 31(1), 15-26.

Clements, R.(2004) An investigation of the status of outdoor play. Contemporary Issues in Early Childhood, 5(1).

Davis, Julie M. (2009) Revealing the research 'hole' of early childhood education for sustainability : a preliminary survey of the literature. Environmental Education Research, 15(2). pp. 227-241.

Singer, D.G., Singer, J.L., D’Agostino, H., \& DeLong, R.(2009). Children's pastimes and play in sixteen nations: Is free-play declining? American Journal of Play, 1(3).

Samuelsson, I.P (2011). Why we should begin early with ESD: The role of early childhood education. International Journal of Early Childhood, 43(2), 103-118.

SFU News Online (2012, June 21). Childcare centre gets green kudos. SFU News Online. Retrieved http://www.sfu.ca/sfunews/stories/2012/childcare-centre-gets-green$\underline{\text { kudos.html }}$ 
Sobel, David (2008). Childhood and Nature. Stenhouse Publishers.

Sobel, David (1999). Beyond Ecophobia: Reclaiming the Heart in Nature Education. Orion Society.

Palmer, J.A., Suggate, Jennifer., Robottom, I., \& Hart, P (1999). Significant life experiences and formative influences on the development of adults' environmental awareness in the UK, Australia and Canada. Environmental Education Research, 5(2) 181-200

Wells, Nancy M., \& Lekies, K, S. (2006). Nature and the life course: Pathways from childhood nature experiences to adult environmentalism. Children, Youth and Environments, 16(1), 1-24.

Wilson, R. A (1996). Starting early: Environmental education during the early childhood years. ERIC Clearinghouse for Science Mathematics and Environmental Education 